\title{
An Exploration of Interpersonal Functions in Iranian Advanced EFL Classrooms
}

\author{
Davud Kuhi $^{1} \&$ Anisa Seyed-Piran ${ }^{1}$ \\ ${ }^{1}$ Department of Foreign Languages, Maragheh Branch, Islamic Azad University, Maragheh, Iran \\ Correspondence: Anisa Seyed-Piran, No. 44, Moeni Alley, Basij St., Imam Ave., Urmia, Iran. Tel: 98-914-345-5326. \\ E-mail: anisa.seyedpiran@gmail.com
}

Received: November 19, 2013 Accepted: December 6, 2013 Online Published: December 20, 2013

doi:10.5430/ijelt.v1n1p83 URL: http://dx.doi.org/10.5430/ijelt.v1n1p83

\begin{abstract}
The research explores an aspect of teacher-learner and learner-learner interaction in Iranian EFL classroom discourse. Based on the assumption that classroom interaction is inherently a dialogue among teacher and learners, this study looks in detail at key aspects of the ways in which Iranian EFL teachers and learners interact with each other, bring their interactants into the context, and involve them in the construction of the discourse and the arguments in order to contribute to the interactiveness and persuasiveness of the oral discussion in the classroom. To do so, Interpersonal Metadiscourse Resources - Stance and Engagement- are looked at in a corpus totally 14,249 words produced orally by Iranian EFL teachers and female learners at advanced proficiency level in 15 sessions. The oral discussions were transcribed and analyzed using frequency frameworks and formulas. The results reveal that the teachers and learners use stance and engagement markers one about every four words and that both use the devices for fairly similar purposes. The findings, however, show noticeable quantitative differences: the teacher use Interpersonal Metadiscourse Resources more frequently than the learners. The teachers, also, use engagement markers considerably more frequently than stance markers; whereas EFL learners use both use stance markers and engagement markers almost equally. The quantitative differences seem to be related to the teachers' expertise in English language as well as the teachers' awareness of metadiscourse. The pedagogical implications of the study for novice EFL teachers, learners and material developers are outlined.
\end{abstract}

Keywords: Interpersonal metadiscourse, Stance, Engagement, EFL classroom, Teacher-Learner interaction, Learner-Learner interaction

\section{Introducation}

\subsection{Metadiscourse and Classroom Interaction}

Hyland (2005a) believes that a text has to talk to readers or hearers in ways that they find familiar and acceptable, Hyland (2005a) believes that a text has to talk to readers or hearers in ways that they find familiar and acceptable, which mean that the process of comprehension and participation is not just matter of informational clarity, but of the individual writer's or speaker's projection of a shared context. In other words, when the senders pursue their personal and professional goals, they try to embed their discourse in a particular social context which they reflect through a particular recognized and accepted discourse.

Cazden (1988) sees language classrooms as sociolinguistic environments and Hall and Versplaetse (2000) consider language classrooms as discourse communities in which interaction contributes to language learners' language development. According to Hall and Verplaetse (2000), interactive processes are not strictly individual or equivalent across learners and situations; language learning is a social enterprise, jointly constructed, and intrinsically linked to learners' repeated and regular participation in classroom activities.

Hall and Verplaetse (2000) state the important role of interaction in additional language learning. They believe that it is in their interactions with each other that teachers and learners work together to create the intellectual and practical activities that shape both the form and the content of the target language as well as the processes and outcomes of individual development.

According to Allwright's (1984, p.158) claims on the importance of classroom interaction in language learning, in foreign language lessons it is "inherent in the very notion of classroom pedagogy itself". 
As Walsh (2006) proposes, interaction in L2 classrooms is essential for language learning to take place, as much of the learning during language lessons occurs through such interactions. Some other, like van Lier (1996), argues that "interaction is the most important element in the curriculum" (p. 5).

According to Hyland (2005b), interaction in academic writing essentially involves adopting a point of view in relation to both the issues discussed in the text and to others who hold points of view on those issues. These interactions are managed by writers in two main ways: stance and engagement.

Hyland (2005b) defines stance as an attitudinal dimension whichincludes features that refer to the ways writers present themselves and convey their judgements, opinions, and commitments. He believes that it is the ways that writers intrude to stamp their personal authority onto their arguments or step back and disguise their involvement. He also defines engagement as a dimension where writers acknowledge and connect to others, recognizing the presence of their readers, pulling them along with their argument, focusing their attention, acknowledging their uncertainties, including them as discourse participants, and guiding them to interpretations. This interpersonal function is investigated by Hyland (1998), who argues that the "sense of audience is critical" because the perceived truth of the arguments themselves requires the linguistic choices to be persuasive (p. 439). Hyland (1988) shows how specific markers in this metadiscourse constitute "the central pragmatic construct which allows us to see how writers seek to influence readers' understandings of both the text and their attitude towards its content and its audience" (p. 437).

Although Hyland's $(1998 ; 2005 a$; 2005b) focus is on writing, it is clear that his theoretical framework also can be applied for the interpersonal dimension of EFL oral discussions and presentations.Accordingly, this study aims to involve observation, identification, and analysis of Interactional Meta-discourse of an Advanced EFL classroom in Iranian context. The purpose is to investigate the interpersonal dimension of classroom discourse by exploring the interaction between EFL teacher and learners, and interaction among learners based on two interpersonal macro-functions of discourse: Stance and Engagement.

\subsection{Statement of the Problem and Purpose of the Study}

The spread of English as an academic language and language of professional activity in EFL contexts has been widely acknowledged. In Iran, one of the central tasks which is a key requirement of all standard EFL courses is oral discussion, yet little in-depth research has been conducted on students' spoken texts in EFL contexts.

Metadiscourse is a widely used term in recent discourse analysis, and is a relatively new approach that refers to the ways in which writers or speakers project themselves to interact with their receivers. It is a concept which sees writing or speaking as a social engagement (Hyland, 2005; Dafouz-Milne, 2008). It is, therefore, believed to play an important role in organizing the discourse, engaging the audience and signaling the writer's or speaker's attitude (Fuertes-Olivera et al., 2001).As a result, it has been taken up and used by researchers to trace patterns of EFL classroom interactions, and to discuss different aspects of L2 interaction In EFL classrooms. In the same line of research the present study aimed at observing and exploring the interpersonal factions of Iranian advanced learners while interaction with their teacher and classmates.

Furthermore, despite variety research on the analysis of metadiscourse resources of interaction between the reader and the writer in EFL academic contexts, no research has been done to explore the interpersonal metadiscourse resources in the interaction between teacher and learner while oral discussion.

The results of this study will enable researchers to see what interactional metadiscourse markers and to what extent are blurt in Iranian advanced learners' speech while oral interaction with the teacher and other learners. This study is also significant because it is the first study that has been undertaken in an Iranian EFL context where the exploration of interpersonal functions of advanced EFL learners, namely, engagement and stance, have never been done in oral context.

This study, in this sense, has been expected to make an important contribution to implications of classroom discourse in EFL setting.

\subsection{Research Question}

To meet this objective, the following main research question is formulated:

"How are interpersonal functions utilized in teacher-learner and learner-learner interactions in Iranian advanced EFL classrooms?"

\section{Review of the Related Literature}

Hyland (2008) believes that the motivation for the writer-reader interactions lies in the fact that readers can always 
refute claims and it gives them an active role in how writers construct their arguments. He believes that any successfully written text anticipates a reader's response and itself responds to a larger discourse already in progress. This locates the writer intertextually within a larger web of opinions (Bakhtin, 1986, cited in Hyland, 2008), and within a community whose members are likely to recognize only certain forms of argument as valid and effective.

These interactions are managed by writers in two main ways: Stance and Engagement. Hyland's (2008) dichotomous notion of stance - "features which refer to the ways writers present themselves and convey their judgments, opinions, and commitments" and engagement -

"an alignment dimension where writers acknowledge and connect to others, recognizing the presence of their readers, pulling them along with their argument, focusing their attention, acknowledging their uncertainties, including them as discourse participants, and guiding them to interpretations"(p.176)- might help better grasp the difference between these two categories of metadiscourse.

Hyland (2008) believes that interactions are accomplished in academic writing by making choices from the interpersonal systems of stance and engagement. He defines stance as the writer's textual voice or community recognized personality, an attitudinal, writer-oriented/speaker-oriented function which concerns the ways writers or speakers present themselves and convey their judgments, opinions, and commitments. Engagement, on the other hand, is more of an alignment function, concerning the ways that writers or speakers rhetorically recognize the presence of their readers to actively pull them along with the argument, include them as discourse participants, and guide them to interpretations (Hyland, 2001). Together they recognize that statements need to both present the writer and his or her ideas as well as anticipatereaders' possible objections and alternative positions, incorporating an appropriate awareness of self and audience. The key resources by which these interactional macro-functions are realised are summarised in Figure 1.

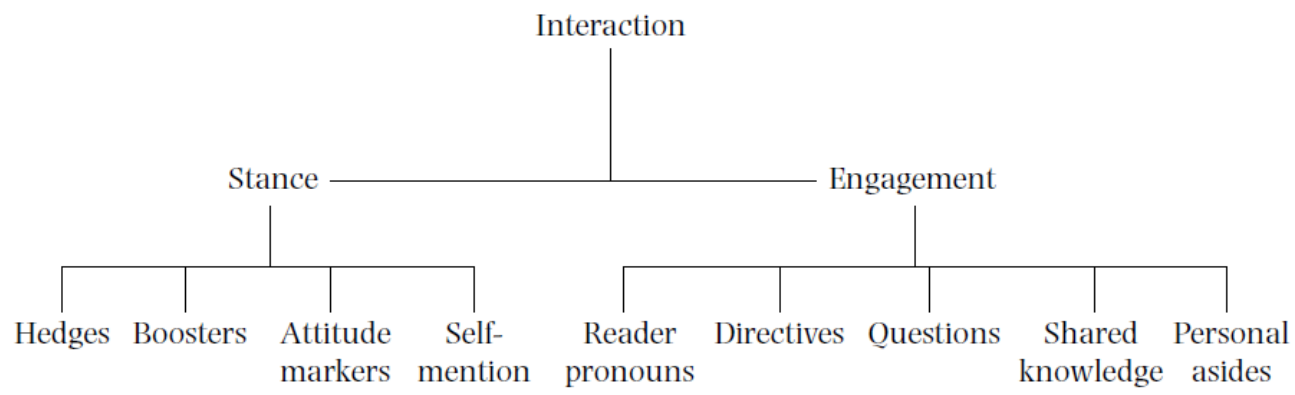

Figure 1. Key resources of academic interaction

A detailed introduction of stance and engagement and their resources will be mentioned on the forthcoming pages.

\subsection{Stance}

Drawing on Hyland's interpersonal model of metadiscourse (Hyland, 2005b, p. 49), the term 'stance' is used here to cover markers indicating the author's attitude to the topic under discussion, markers building his/her relationship with readers by opening a dialogic space for the negotiation of meaning and markers indicating discourse organization. Stance is known under different labels and overlaps to various degrees and is defined as expressing personal feelings, attitudes, value judgements, or assessments (Biber et al., 1999) added to the propositional content, different grammatical and lexical markers. By lexical stance refers to affective or evaluative word choice that involves a single proposition. lexical stance is different from grammatical stance marking. While in lexical stance marking value-laden words are used, grammatical stance markers do not provide an attitudinal or evaluative frame for some other proposition. The existence of a stance is inferred from the use of an evaluative lexical word like an adjective, main verb or noun.

According to Hyland $(2008,2010)$, therefore, stance is writer-oriented features of interaction which includes different kinds of personal feelings, attitudes that a writer has about particular information, how certain fellings are about its veracity, how these feelings obtained access to it, and what perspective they are taking to it and to the reader. It has three broad meanings:

- Evidentiality, or the writer's commitment to the reliability of propositions and their potential impact on readers;

- Affect, or personal and professional attitudes towards what is said; 
- Presence, or how far writers choose to project themselves into a text.

Briefly, as Hyland (2005b, 2008) maintains, it is comprised of hedges, boosters, attitude markers, and self mention.

Hedges are devices which express complete commitment to a proposition and allow information to be presented as an opinion rather than fact (Hyland, 1998). Hyland implies that a claim is based on plausible reasoning rather than certain knowledge and so both indicate the degree of confidence it might be wise to attribute to a claim while allowing writers to open a discursive space for readers to dispute interpretations.

Boosters (like, definitely, sure, prove, etc.) allow writers to express certainty. This certainity refers to in what they say and to mark involvement with the topic and solidarity with readers. While they restrict opportunities for alternative voices, they also often stress shared information and group membership as we tend to get behind those ideas which have a good chance of being accepted. Like hedges, boosters usually occur in clusters, emphasizing the writer's conviction in an argument.

Attitude markers refer to the writer's attitude to propositions. They convey surprise, agreement, importance, frustration, and so on, rather than commitment (Hyland, 2005b, 2008, 2010). This is affect, not epistemology. This allows writers to both take a stand and align themselves with disciplinary value positions. Attitude is most explicitly indicated by attitude verbs, sentence adverbs, and adjectives, and this marking of attitude in academic writing allows writers to both take a stand and align themselves with disciplinary-oriented value positions.

Self mention is to the use of first person pronouns and possessive adjectives to present information (Hyland, 2001). According to (Ivanic, 1998), in the writing process, presenting a discoursal self is a central issue. Therefore, the writer cannot avoid projecting an impression of him/her and how he/she stand in relation to his/her arguments, discipline, and readers. It is up to the writer to choose a particular stance and disciplinary-situated authorial identity, which can include the presence or absence of explicit author reference.

\subsection{Engagement}

The ways writers bring readers into the discourse to anticipate their possible objections and engage them in appropriate ways is engagement (Hyland, 2005a, 2005b, 2008, 2010). In comparison with stance and according to Hyland (2005a), engagement has been relatively neglected in the literature. Writers make predictions about how readers are to react to their arguments, based on the readers' previous experiences with texts. The writers know what the readers are likely to find persuasive, where they will need help in interpreting the argument, what objections they are likely to raise, and so on. Hyland (2001) believes that the process of audience evaluation therefore will help writers in making an effective line of reasoning and will point to the ways language is related to specific cultural and institutional contexts.

Hyland (2005a) suggests two main purposes in using engagement strategies in writing to the authors; first, to meet readers' expectations of inclusion and disciplinary solidarity adequately, because the readers are addressed as participants in an argument with reader pronouns and interjections; second, to position the audience rhetorically, because the readers are pulled into the discourse at critical points, predicting possible objections and guiding them to particular interpretations with questions, directives and references to shared knowledge by the writers.

According to Hyland (2008), engagement seeks to build a connection with readers to both stress solidarity and position them by anticipating possible objections and guiding their thinking. The writers, based on their previous experiences with texts, make predictions about how readers are to react to their arguments and craft their texts to explicitly address them at certain points (Hyland, 2001). Engagement markers, as Hyland (2005b, 2008) states, include reader pronouns, personal asides, references to sharedness, directives, and questions.

Reader pronouns offer the most explicit ways of bringing readers into a discourse, but we almost never find "you" in academic writing, perhaps because it implies a separation between writer and reader, rather than seeking connections. Instead there is enormous emphasis on binding the two together through the use of inclusive "we." The most important reason for using this form is that it identifies the reader as someone who shares similar interests or ways of seeing to the writer as a member of the same discipline. At the same time as expressing peer solidarity, however, it also anticipates reader objections, presuming mutual understandings while inserting the readers' potential point of view into the argument.

Directives are mainly expressed through imperatives and obligation modals and direct the readers to engage in three kinds of activity:

- textual acts which direct readers to another part of the text or to another text (see VanPatten, 2004; refer to figure 3 , etc.) 
- physical acts which direct readers how to do some acts in the real situations (e.g., open the door, turn off the TV).

- cognitive acts which teach the readers how to interpret an argument and explicitly positioning the readers by encouraging them to note, concede or consider some argument in the text.

By using personal asides, the writers address readers directly by interrupting the argument to give a comment on what has been said. By turning to the reader in middle of the argument, writers can initiate a brief dialogue that increases the writer-reader relationship.

Appeals to shared knowledge refer to explicit signals by which readers can recognize something as familiar or accepted. These constructions of solidarity ask readers to identify with particular views and so construct readers by giving them a role in argument construction and moving the focus of the discourse from the writer to creat the role of the reader.

Questions are key strategies of dialogic involvement which invite participation, encourage curiosity and lead the readers to the writer's viewpoint (Hyland, 2002). Questions carry out a series of functions in academic writing and can have different effects from the naive puzzlement of limited knowledge to the confident prediction of reaching an answer. All the time, though, they invite direct collusion because they address the reader who is interested in the issue the question raises and the good sense to follow the writer's response to it. Example:

Is it, actually, easy for a woman to choose between family and career? I think it is not.

\section{Methodology}

\subsection{Participants}

In this research, 80 EFL learners in five advanced EFL classes of Andishe-ye- Sabz institute (in Urmia, Iran) served as samples for the study. The number of participants in every class was between 14 and17. The age range of EFL learners were between 16 and 24. All the participants were female with a bilingual background, i.e. Turkish and Persian. Only one teacher taught in all five classes. The teacher proposed for the present study was male with and M.A degree in TEFL) and had adequate experience of teaching English in Iran.

\subsection{Instrumentation}

The only way to collect data useful for this study was observation. To meet the purpose of the study, the following instruments were used:

1. A voice recorder for collecting data

2. The sections of the textbooks pre-selected for discussion sessions of Advanced EFL learners

\subsection{Procedure}

First, the researcher chose five Advanced EFL classes, with 14-17 female learners in each class, in Andishe-ye- Sabz Institute. All five classes were managed by the same teacher. Then the recordings were conducted by a voice recorder for 3 sessions in each class (totally 15 sessions). In order to have more evidence of teacher-learner and learner-learner interactions in the present study, the researcher included the discussion sessions in her research, only. Each discussion session lasted for about 30-45 minutes. In order to obtain authentic data, the teacher and the learners were informed about recording of their class. After recording, the researcher let them know and asked permission for working on their audio-recorded class. The teacher followed the institute's syllabus an there was no instruction to the teacher by the researcher in order to obtain authentic data record. Then, the audio-recorded data were listened and transcribed Then the researcher analyzed the data in order to find a reasonable answer to the research question. .

To investigate interpersonal functions of the Teacher-Learner Interaction and Learner-Learner Interaction, Hyland's (2005a) model was utilized. First, related sections of transcriptions, regarding Hyland's (2005a) framework of interpersonal metadiscourse resources, were read carefully by the researcher to identify both stance and engagement resources. Then, the researcher made use of frequency counts to analyze the data in the study. Frequency counts (the below formula) was used to show the frequency of different interpersonal metadiscoursal categories as found in the EFL classroom transcriptions.

IMRs belonbing to each category

$$
\text { F per } 1000 \text { words }=\frac{}{\text { the total number of words in classroom interaction }} \times 1000
$$


Also, the researcher took advantage of percentage figures by means of the following formula (Hyland, 2005a) to show the distribution of each metadiscourse item in Teacher-Learner interaction as well as in Learner-Learner interaction.

$$
\text { Percent }=\frac{\text { IMRs belonbing to each category }}{\text { the total number of IMRs in classroom interaction }} \times 100
$$

\section{Results}

As it was mentioned earlier, discussion sections of Iranian EFL classrooms were analyzed to characterize difference between Teacher-Learner and Learner- Learner interaction in terms of interpersonal metadiscourse resources, stance and engagement. Here, the frequency of interpersonal metadiscourse resources was counted and calculated per 1,000 words. Table 1 shows the total frequency of interpersonal metadiscourse resources (IMR) in total words spoken in the classrooms per 1000 words as well as percentage of the frequency.

Table 1. Frequency of Interpersonal Metadiscourse Resources in EFL Classrooms

\begin{tabular}{llll}
\hline & Raw Number & FrequencyPer 1000 Words & Percent \\
\hline IMRs & 3375 & 236.8 & 23.6 \\
Words Spoken & 14249 & 1000 & 100 \\
\hline
\end{tabular}

As it can be seen in Table 1, the total frequency of IMRs was 236.8 per 1000 words. In the other words $23.6 \%$ of words spoken in the EFL classrooms are IMRs.

Table 2 shows the number and the frequency of stance markers and engagement markers used in EFL classroom discussions.

Table 2. Frequency of Stance and Engagement markers in EFL Classrooms

\begin{tabular}{llll}
\hline & Raw Number & FrequencyPer 1000 Words & Percent \\
\hline Stance & 900 & 63.16 & 26.6 \\
Engagement & 2475 & 173.69 & 73.3 \\
IMRs & 3375 & 236.8 & 100 \\
\hline
\end{tabular}

According to Table 2, engagement markers with $73.3 \%$ were the most frequent IMRs used in EFL classrooms and they were used nearly three times more than stance markers, which were used with $26.6 \%$ of frequency.

In the next table, the frequency of the sub-categories of stance markers and their percentage of use in the classrooms are shown.

Table 3. Frequency of Sub-categories of Stance Markers in EFL Classrooms

\begin{tabular}{lllll}
\hline & & Raw Number & FrequencyPer 1000 Words & Percent \\
\hline \multirow{4}{*}{ Stance } & Hedges & 315 & 22.1 & 22.1 \\
Markers & Boosters & 321 & 22.52 & 22.52 \\
& Attitude Markers & 20 & 1.4 & 1.4 \\
& Self-Mentions & 244 & 17.12 & 17.12 \\
& Stance & 900 & 63.1 & 63.1 \\
\hline
\end{tabular}


Table 4. Frequency of Sub-categories of Engagement Markers in EFL Classrooms

\begin{tabular}{lllll}
\hline & & Raw Number & FrequencyPer 1000 Words & Percent \\
\hline \multirow{4}{*}{ Engagement } & Interactant Pronouns & 423 & 29.68 & 12.53 \\
Markers & Directives & 758 & 53.19 & 22.45 \\
& Questions & 944 & 66.25 & 27.97 \\
& Appeals to Shared & 350 & 24.56 & 10.37 \\
& Knowledge & & & 73.3 \\
\hline
\end{tabular}

According to the table 4, questions and directives are the most frequent engagement markers used in the EFL classroom context with $27.97 \%$ and $22.45 \%$, respectively, and appeals to shared knowledge are the least frequent ones with $10.37 \%$. This shows that questions and directives play vital roles among teachers and learners in EFL classroom contexts.

\subsection{Stance and Engagement Comparison in Teacher-Learner and Learner-Learner Interaction}

In earlier parts of this chapter, the frequency of IMRs, stance markers, and engagement Markers as well as their sub-categories in EFL classroom context were calculated separately. In this section, these interpersonal functions' frequencies will be compared in terms of Teacher-Learner and Learner-Learner Interaction. Table 5 compares the number and frequency of IMRs, stance markers, and engagement Markers in terms of Teacher-Learner interaction (teacher as Speaker), Learner-Teacher interaction (learners as speaker) and Learner-Learner Interaction.

Table 5. Frequency of IMRs Used by Teachers and Learners

\begin{tabular}{|c|c|c|c|c|c|c|}
\hline & \multicolumn{2}{|l|}{ IMRs } & \multicolumn{2}{|c|}{ Stance Markers } & \multicolumn{2}{|c|}{ Engagement Markers } \\
\hline & Number & Percent & Number & Percent & Number & Percent \\
\hline Teacher-Learner & 2400 & $71.11 \%$ & 378 & $11.2 \%$ & 2022 & $59.91 \%$ \\
\hline Interaction & & & & & & \\
\hline Learner-Teacher & 656 & $19.43 \%$ & 346 & $10.25 \%$ & 310 & $9.18 \%$ \\
\hline Interaction & & & & & & \\
\hline Learner-Learner & 319 & $9.45 \%$ & 176 & $5.21 \%$ & 143 & $4.24 \%$ \\
\hline Interaction & & & & & & \\
\hline
\end{tabular}

Considering Table 5, IMRs used in Teacher-Learner interaction has the highest number, 2400, and IMRs belonging to Learner-Learner interaction has the lowest number, 319.

Moreover, both stance markers and engagement markers used in Teacher-Learner interaction has the highest number, 378 and 2022, respectively. Stance markers and engagement markers used in Learner-Learner interaction has the lowest number, 176 and 143, respectively.

\subsection{Stance Sub-categories Comparison in Teacher-Learner and Learner-Learner Interaction}

For more detailed results, the frequencies of subcategories of Stance- hedges, boosters, attitude markers, self mention- are compared in terms of Teacher-Learner and Learner-Learner Interaction, too. Table 6 compares the number and frequency of Stance Markers in terms of Teacher-Learner interaction (teacher as Speaker), Learner-Teacher interaction (learners as speaker) and Learner-Learner Interaction. 
Table 6. Frequencies of Stance markers Used by Teachers and Learners

\begin{tabular}{|c|c|c|c|c|c|c|c|c|}
\hline & \multicolumn{2}{|l|}{ Hedges } & \multicolumn{2}{|l|}{ Boosters } & \multicolumn{2}{|c|}{ Attitude Markers } & \multicolumn{2}{|c|}{ Self mentions } \\
\hline & Number & Percent & Number & Percent & Number & Percent & Number & Percent \\
\hline $\begin{array}{l}\text { Teacher-Learner } \\
\text { Interaction }\end{array}$ & 45 & $1.33 \%$ & 276 & $8.18 \%$ & 13 & $0.39 \%$ & 44 & $1.3 \%$ \\
\hline $\begin{array}{l}\text { Learner-Teacher } \\
\text { Interaction }\end{array}$ & 184 & $5.45 \%$ & 33 & $0.98 \%$ & 6 & $0.18 \%$ & 123 & $3.64 \% \%$ \\
\hline $\begin{array}{l}\text { Learner-Learner } \\
\text { Interaction }\end{array}$ & 86 & $2.54 \%$ & 12 & $4.05 \%$ & 1 & $0.03 \%$ & 77 & $2.28 \%$ \\
\hline $\begin{array}{l}\text { Mean Use of } \\
\text { Items }\end{array}$ & 105 & $3.11 \%$ & 107 & $3.17 \%$ & 6.67 & $0.2 \%$ & 81.33 & $2.41 \%$ \\
\hline $\begin{array}{l}\text { In classroom } \\
\text { interaction }\end{array}$ & & & & & & & & \\
\hline
\end{tabular}

According to table 6, the highest frequency of hedges use belongs to Learner-Teacher interaction, with 5.45\%. Boosters are used mostly in Teacher-Learner interaction, with $8.18 \%$. Although attitude markers are used mostly in Teacher-Learner interaction, with $0.39 \%$, but it is the least used stance marker in classroom oral discourse, with less than one percent in total use of IMRs, whether by the teachers or the learners. Self-mentions, as another sub-category of stance markers, are used most frequently in Learner-Teacher interaction, with 3.64\%. According to this table 3, the most frequent stance marker is booster and is used by the teachers in their interaction with learners. Generally, however, hedges and boosters are most common stance markers which are applied in classroom discourse and the mean use of hedges and boosters in EFL classrooms under investigation are $3.11 \%$ and $3.17 \%$, respectively.

\subsection{Engagement sub-categories Comparison in Teacher-Learner and Learner-Learner Interaction}

For obtaining more precise information, the frequencies of subcategories of engagement- interactant pronouns, directives, questions, and appeals to shared knowledge- are compared in terms of Teacher-Learner and Learner-Learner Interaction, too. Table 7 compares the number and frequency of engagement Markers in terms of Teacher-Learner interaction (teacher as Speaker), Learner-Teacher interaction (learners as speaker) and Learner-Learner Interaction.

Table 7. Frequencies of Engagement markers Used by Teachers and Learners

\begin{tabular}{|c|c|c|c|c|c|c|c|c|}
\hline & \multicolumn{2}{|c|}{ Interactant Pronouns } & \multicolumn{2}{|c|}{ Directives } & \multicolumn{2}{|c|}{ Questios } & \multicolumn{2}{|c|}{ Appeals to Knowledge } \\
\hline & Number & Percent & Number & Percent & Number & Percent & Number & Percent \\
\hline $\begin{array}{l}\text { Teacher-Learner } \\
\text { Interaction }\end{array}$ & 337 & $9.99 \%$ & 684 & $20.27 \%$ & 726 & $21.51 \%$ & 275 & $8.15 \%$ \\
\hline $\begin{array}{l}\text { Learner-Teacher } \\
\text { Interaction }\end{array}$ & 66 & $1.96 \%$ & 20 & $0.6 \%$ & 196 & $5.81 \%$ & 28 & $0.83 \%$ \\
\hline $\begin{array}{l}\text { Learner-Learner } \\
\text { Interaction }\end{array}$ & 20 & $0.6 \%$ & 54 & $1.6 \%$ & 22 & $0.65 \%$ & 47 & $1.39 \%$ \\
\hline $\begin{array}{l}\text { Mean Use of } \\
\text { Items }\end{array}$ & 141 & $4.17 \%$ & 252 & $7.46 \%$ & 315 & $9.33 \%$ & 117 & $3.47 \%$ \\
\hline $\begin{array}{l}\text { In classroom } \\
\text { interaction }\end{array}$ & & & & & & & & \\
\hline
\end{tabular}

According to table 7, the highest frequency of interactant pronouns use belongs to Teacher-Learner interaction, with 9.99\%. Directives are used mostly in Teacher-Learner interaction, with $20.27 \%$. Questions are used mostly in Teacher-Learner interaction, with $21.51 \%$. According to this table, all sub-categories of Engagement are used by teachers in their interaction with learners with a great degree of frequency difference.

Generally, teachers, as experts in EFL, use engagement markers frequently to take advantage of them to facilitate 
their interaction with the learners. Although, directives are the most frequent engagement markers that are used by the teachers in classroom interaction, questions are the most common engagement markers which are applied in classroom discourse in general and directives follow them. The mean use of questions and directives in EFL classrooms under investigation are $9.33 \%$ and $7.46 \%$, respectively.

\section{Discussion}

According to Hyland (2005b), stance refers to the writer/ speaker's voice, an attitudinal writer/speaker-oriented function which concerns the ways writers/ speakers present themselves and convey their opinions and commitments. Engagement is more of an alignment function, concerning the ways that writers/ speakers rhetorically recognize the presence of the readers/ listeners and trying to pull the readers/listeners actively along with the argument. By Engagement, writers/ speakers include readers/ listeners as discourse participants, and guide them to interpretations (Hyland, 2001). Together they recognize that statements need to both present the writer/speaker and his or her ideas as well as anticipate readers/listeners' possible objections and alternative positions, incorporating an appropriate awareness of self and audience (Hyland, 2005b).

As the results of the current study showed, teachers and learners, tended to use interpersonal metadiscourse resources in EFL classroom interactions. It should be said that interactant involvement through such resources can contribute to the persuasiveness and argumentativeness of classroom discourse. It shows that that the expression of stance and engagement is an important feature of EFL classroom interaction, with 237 occurrences in each 1000 woeds, about one everyfive words. The results showed that engagement markers were about three times more common than stance markers. While hedges and boosters were the most common stance markers, questions were the most regular engagement markers in EFL classroom discourse. Hedges and booster, as stance markers, occurred one about every ten IMRs and questions and directives, engagement markers, one about every five IMRs. Going on detail, teachers used engagement markers about six times more than stance markers in interaction with the learners. Learners, however, used both stance markers and engagement markers, somehow, equally either in interaction with the teachers or the learners.

Counting and categorizing markers of interaction provided information about the relatively high use of markers of interaction that could be observed in Teacher-Learner and Learner-Learner interactions. The numbers suggest that the level of interaction is far more extensive in Teacher-Learner interaction than in Learner-Learner interaction. While the numbers indicate a relatively high degree of interaction, the process of identifying the markers revealed reasons to be cautious in interpreting the numbers at face value.

This analysis was a process which provided insight into the functions of the markers that must be considered in any interpretation of the numbers. On the whole, the analysis revealed a qualitatively deeper level of interaction and reflection than was reflected in the numbers. The researcher identified some reasons for the variety and the relative incidence of markers in teacher-learner and learner-learner interactions.

\section{Hedges and Boosters}

While both teachers and learners used hedges in their statements, they were more frequent by the learners in interaction with their teachers, perhaps indicating less assurance about what the teachers were assumed to accept.

One reason for using more hedges by the learners in interaction with the teachers is that "arguments have to be expressed more cautiously remaining open to diversity" Hyland (2008, p.14).

Boosters, on the other hand were used more frequently by the teachers. Teachers took advantage of the boosters to establish the significance of the claims against the learners' interpretations. This means that the teachers restricted the learners' interpretations by using boosters.In Learner-Learner interaction, howerever, hedges and boosters were used at least. The less frequent use of hedges and boosters by the learners might be one way of minimizing the role of their classmates in classroom discussions and downplying their position in discussions.

\section{Self-mention and Attitude markers}

Self-mention and attitude markers are less common in classroom discourse, especially in Teacher-Learners interaction. This is because the teachers are concerned with more generalizations rather than individuals and with strengthening the objectivity of their interpretations. In the Learner-Teacher, however, interaction where what counted as adequate explanation was less assured, interpretative variation increased and the learners relied to a greater extent on personal projection into the discussion, through self-mention and attitude markers to invoke a credible speaker. Besides creating an impression of authority, integrity and credibility through choices from the stance markers, both the teachers and the learners were able to either highlight or downplay the presence of their 
interactants in the classroom discourse by engagement markers.

\section{Questions and Direvtives}

As it was seen, the most frequent engagement devices in the classroom discourse were questions and directives. There was a greater imbalance with the use of questions and directives in Teacher-Learner interaction in comparison with Learner-Teacher and Learner-Learner interactions. Directives and questions were by far the most frequent features of teacher perspective in the classroom discourse, reflecting the importance of the fact from opinion and the need for the teachers to present their claims with appropriate way and regard to the learners' needs.

Questions which were almost exclusively confined to Teacher-Learner interactions, served to structure the interaction and rhetorically the position of the learners. By rhetorical questions, presenting an opinion as an interrogative, the teachers tried to initiate a dialogue and engage the learners and closing it to present a claim. Directives, on the other hand, were other engagement markers which occurred more frequently in Teacher-Learner interactions than in Learner-Teacher and Learner-Learner interactions. Generally, directives, as one of explicit engagement markers, are a feature of Teacher-Learner interaction, where the teachers were not so able to rely on the explanatory value of accepted procedures. That is, directives instruct the learners to act, see or do thing in a certain way rather than informing them how they can interpret an argument.

\section{Interactant Pronouns and Knowledge Sharedness}

Interactant pronouns were used mostly by the teachers to claim authority as well as commonality. The use of interactant pronouns might lead the teachers to employ a conversational tenor in which the teacher and the learners interact most explicitly.

The instances of "appeal to shared knowledge' were so infrequent. Again, they were considerably frequent in Teacher-Learner interaction. This might show the teacher's hope in involving the learners in the arguments more frequently by assuming a certain amount of shared knowledge, experience, beliefs, goals, etc. The results of the study, as related to the use of engagement and stance markers in classroom interaction, are in line with findings of the previous projects on the issue (Hyland, 2005a; Hyland, 2005b; Abdi, 2002; Hyland, 2010).

The results show these different features are important ways of presenting EFL classroom discourse in the interactions of teacher and learners. This Study confirms Hyland's (2005b) suggestion that stance and engagement represent relatively conventional ways of making meaning and so elucidate a context for interaction and interpretation (Hyland, 2010), showing how the teachers and the learners make connections to their interactants using them.

\section{Conclusion and Pedagogical Implications}

According to the current study, distribution of both stance markers and engagement markers' use varied in EFL classroom interactions among the teacher and the learners. Based on the results of the study, engagement markers were used about three times more than stance markers in EFL classroom context, in general. Although, both stance markers and engagement markers are important ways of situating EFL classroom discourse in the interactions of members of classroom- teacher and learners, it can be said that hedges and boosters as well as questions and directives are the most vital features in classroom interactions. Stance and engagement represent different ways of making meaning and so create a context for interaction and interpretation, showing how the teachers and the learners can make connections to their interactants using them. Moreover, more frequent use of IMRs, Stance and engagement, by the teachers, as experts, does show the significance of these features in EFL classroom discourse, too.

The findings contribute to our growing understanding of how teachers and learners deploy these resources to interact with their interactants. The findings showed that stance markers and engagement markers are employed for fairly similar purposes by both teachers and learners but there are considerable distributional differences in their frequencies, with teachers noticeably overusing the interactional resources.

The findings of this study, therefore, might have relevance for the expertise of the EFL teachers, suggesting that EFL learners can benefit from an awareness of appropriate use of stance markers and engagement markers for the purpose of interacting with their teachers and classmates too and building convincing discussions, too. EFL learners should be directed towards dialogue in a way that conforms to the conventions of the target language. If EFL students want to present persuasive discussions that are understood by the interactants, they need to employ these resources as far as possible in the way that native speakers do.

EFL teachers should raise students' consciousness and enhance their sensitivity by showing them the ways native 
speakers employ stance markers and engagement markers effectively in order to involve the interactants in the conversation. Teachers can make use of concordance programs to enable their learners to discover for themselves the rhetorical functions of interactional resources in authentic persuasive contexts made by native speakers.

Therefore, metadiscourse studies can help materials developers, syllabus designers, English language teachers, and above all, EFL learners to realize which rhetorical and linguistic aspects are more essential to be focused upon so that EFL learners and teachers' interactions resemble more closely the native speaker patterns.

\section{References}

Abdi, R. (2002). Interpersonal metadiscourse: an indicator of interaction and identity. Discourse Studies, 4(2). 139-145. http://dx.doi.org/10.1177\%2F14614456020040020101

Allwright, R. (1984). The importance of interaction in classroom language learning. Applied Linguistics, 5(2), pp. 156-171. http://dx.doi.org/10.1093\%2Fapplin\%2F5.2.156

Biber, D., Johansson, S., Geoffrey, L., Conrad, S., \& Finegan, E. (1999). Longman grammar of spoken and written English. London: Longman.

Cazden, C. (1988). Classroom discourse: The language of teaching and learning. Portsmouth, NH: Heinemann.

Dafouz-Milne, E. (2008). The pragmatic role of textual and interpersonal metadiscourse markers in the construction and attainment of persuasion: a cross-linguistic study of newspaper discourse. Journal of Pragmatics, 40(1), pp. 95-113. http://dx.doi.org/10.1016\%2Fj.pragma.2007.10.003

Fuertes-Olivera, A., Velasco-Sacristán, M., Arribas-Baño, A., \& Samaniego-Fernández, E. (2001). Persuasion and advertising English: metadiscourse in slogans and headlines. Journal of Pragmatics, 33(8), pp. 1291-1307. http://dx.doi.org/10.1016\%2FS0378-2166\%2801\%2980026-6

Hall, J. K., \&Verplaetse, L. S. (2000). Second and Foreign Language Learning through Classroom Interaction. Mahwah, N.J.: Lawrence Erlbaum.

Hyland, K. (1998). Persuasion and context: The pragmatics of academic metadiscourse. Journal of Pragmatics, 30(4),437-455. http://dx.doi.org/10.1016\%2FS0378-2166\%2898\%2900009-5

Hyland, K. (2001). Humble servants of the discipline? Self-mention in research articles. English for Specific Purposes, 20(3), 207-226. http://dx.doi.org/10.1016\%2FS0889-4906\%2800\%2900012-0

Hyland, K. (2002). What Do They Mean? Questions in Academic Writing. Text, 22(4), 529-57. http://dx.doi.org/10.1515\%2Ftext.2002.021

Hyland, K. (2005a). Metadiscourse. London: Continuum.

Hyland, K. (2005b). Stance and engagement: A model of interaction in academic discourse. Discourse Studies, 7(2), 173-192. http://dx.doi.org/10.1177\%2F1461445605050365

Hyland, K. (2008). Persuasion, interaction and the construction of knowledge: representing self and other in research writing. International journal of English studies, 8(2), 1-23.

Hyland, K. (2010). Metadiscourse: Mapping interactions in academic writing. Nordic Journal of English Studies, Special Issue: Metadiscourse, 9(2), 125-143.

Ivanič, R. (1998). Writing and identity: the discoursal construction of identity in academic writing. Amsterdam: John Benjamins.

Walsh, S. (2006). Investigating classroom discourse. London: Routledge. 